\title{
Analysis of Meristic Characters and Genetic Differentiation in Greenland Halibut (Reinhardtius hippoglossoides) in the Northwest Atlantic
}

\author{
F. Riget and J. Boje \\ Greenland Fisheries Research Institute, Tagensvej 135 \\ DK-2200 Copenhagen N, Denmark \\ and \\ V. Simonsen \\ National Institute of Animal Sciences, Foulum \\ P. O. Box 39, 8830 Tjele, Denmark
}

\begin{abstract}
A stock identification study of Greenland halibut (Reinhardtius hippoglossoides) in the Northwest Atlantic was carried out based on samples from off eastern Newfoundland, Davis Strait, three West Greenland fjords and Denmark Strait. Meristic characters and frequencies of electrophoretically detectable alleles of protein loci were analyzed.

Mean number of vertebrae showed significant heterogeneity among areas, while fin-ray numbers showed no difference. Offshore areas were very alike in terms of mean numbers of vertebrae, while those from the inshore areas of West Greenland differed both among themselves and from those of the offshore areas.

The genetic variation between samples was small. In all samples the phenotypic distribution of four polymorphic loci was in accordance with the expectation from the Hardy-Weinberg proportions. Pair comparisons of the allelic distributions between samples showed that more than one breeding stock must exist.

Although the Denmark Strait stock could not be separated from the stock in the area between West Greenland and Canada, results support the conclusion that at least two spawning stocks exist in the Northwest Atlantic. Results are consistent with the prevailing theory that Greenland halibut form a single, interbreeding stock in the offshore area between Canada and West Greenland, but also agree with other evidence that Greenland halibut in West Greenland fjords are partially isolated from the offshore stock.
\end{abstract}

\section{Introduction}

Greenland halibut (Reinhardtius hippoglossoides Walbaum) are widely distributed in the Northwest Atlantic. Spawning evidently takes place in the deeper waters of the Davis Strait south of $67^{\circ} \mathrm{N}$ (Jensen, 1935; Smidt, 1969). The larvae are dispersed by the currents both to the west coast of Greenland and to the eastern Canadian coast (Templeman, 1973). While growing up, Greenland halibut in West Greenland migrate both to the Davis Strait (Riget and Boje, 1989) and to the deeper parts of the fjords (Smidt, 1969; Riget and Boje, 1989). On reaching maturity, Greenland halibut in the fjords are assumed to migrate to the spawning area in the Davis Strait (Smidt, 1969).

In the East Greenland/Iceland area, spawning seems to occur on the continental slopes west of Ice- land (Sigurdsson, MS 1980). Eggs and larvae are first carried northwestward and later southwestward toward East Greenland by the Irminger Current or northeastward along the northern Icelandic coast (Sigurdsson, MS 1980). Greenland halibut growing up in the northern area off Iceland are assumed to migrate to the spawning area when they reach maturity. It therefore seems that Greenland halibut in the western North Atlantic (i.e. including Icelandic waters) form two spawning stocks, one in the area between West Greenland and Canada and one west of Iceland, although migrations from West Greenland to Iceland have been observed (Riget and Boje, 1989).

Several studies on stock identification of Greenland halibut in the Northwest Atlantic have been carried out. Templeman (1970) analyzed meristic characters in the Northwest Atlantic including offshore areas off 
West Greenland. He found a significantly higher average number of vertebrae in Gulf of St. Lawrence fish than in fish from elsewhere in the Northwest Atlantic. Misra and Bowering (1984) used a multivariate technique to analyze meristic characters of Greenland halibut in Canadian Atlantic waters and found that Gulf of St. Lawrence and Fortune Bay fish were similar but were separable from those of all other areas. Fairbairn (1981) investigated frequencies of electrophoretically detectable alleles of protein loci among Greenland halibut from Canadian Atlantic waters and found two loci which were polymorphic in all samples. Based on the allele frequencies of these loci she concluded that they form a single homogeneous stock in the Northwest Atlantic area, but that those in the Gulf of St. Lawrence form a separate although not completely isolated stock. Also Khan et al. (1982), analyzing the prevalence of blood Protozoa, concluded that a separate stock occurred in the Gulf of St. Lawrence and was further able to distinguish between Greenland halibut of the Gulf of St. Lawrence and those of Fortune Bay.

These previous investigations on stock identification did not include fish from West Greenland fjords. Recently, Riget and Boje (1989) summarized the present understanding of the biology of Greenland halibut in West Greenland waters. Generally their findings are in agreement with the above described lifecycle but they emphasized that fish in the West Greenland fjords may be regarded as mainly stationary. Furthermore, it seems likely that some spawning takes place in these fjords although it may only be occasionally (Boje and Riget, MS 1988). Riget and Boje (1989) also hypothesized that the fish in the southernmost fjords of West Greenland were to some extent recruited from the spawning grounds west of Iceland. This study was therefore initiated to test the hypotheses that: (a) Greenland halibut in the West Greenland fjords are isolated from the offshore stock or stocks, and (b) Greenland halibut in the southernmost fjords of West Greenland are derived from spawning grounds west of Iceland.

\section{Materials and Methods}

About 100 specimens of Greenland halibut in the length range $50-70 \mathrm{~cm}$ (mainly immature fish) were collected from six localities (Fig. 1 and Table 1). Sex of

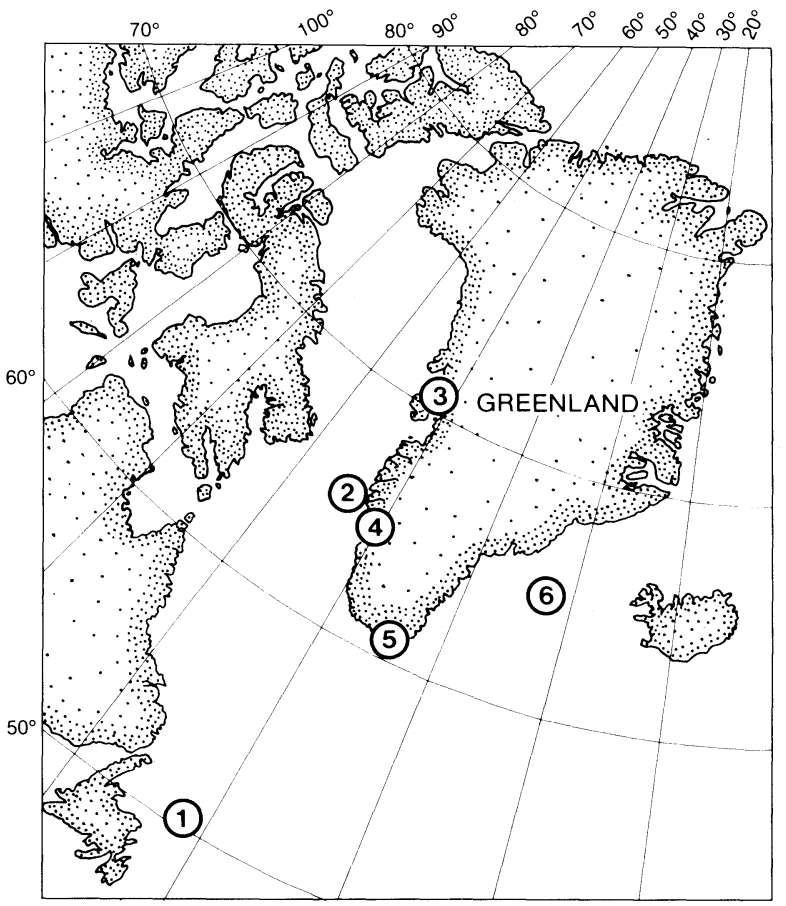

Fig. 1. Distribution of Greenland halibut samples in the Northwest Atlantic. 1: Newfoundland, Div. 3K; 2: Davis Strait, Div. 1C; 3: West Greenland fjords, Div. 1A; 4: West Greenland fjords, Div. 1C; 5: West Greenland fjords, Div. 1F; and 6: Denmark Strait, ICES Subarea XIVb.

all specimens was determined and total length measured.

The vertebral column and the dorsal, anal and pectoral fins were extracted and stored in frozen condition. Frozen samples were thawed in the laboratory and all vertebrae were counted including the urostylar half vertebra. Fish with fused vertebrae were excluded. Some vertebral columns were prepared for counting by cooking to remove the flesh. Fin ray counts were made without any special treatment.

For enzyme studies, eye, heart, liver and muscle samples were taken from each fish immediately after capture, with the exception that no eyes were taken from the fjord sample in Div. 1D. These samples were stored in plastic bags at $-18^{\circ} \mathrm{C}$ for a few months before being used in starch gel electrophoresis. The nomen-

TABLE 1. Periods of sampling and depth interval of sampling sites for Greenland halibut used in this study.

\begin{tabular}{llccc}
\hline \hline $\begin{array}{c}\text { Site } \\
\text { No. }\end{array}$ & Location & $\begin{array}{c}\text { NAFO Division/ } \\
\text { ICES Subarea }\end{array}$ & Date & $\begin{array}{c}\text { Depth } \\
\text { interval } \\
(\mathrm{m})\end{array}$ \\
\hline (1) & Newfoundland & $3 \mathrm{~K}$ & Nov-Dec 1987 & $220-835$ \\
$(2)$ & Davis Strait & $1 \mathrm{C}$ & Sep 1988 & $603-869$ \\
$(3)$ & West Greenland fjords & $1 \mathrm{~A}$ & Aug 1987 & $210-1080$ \\
$(4)$ & West Greenland fjords & ID & Jan 1987 & $140-600$ \\
$(5)$ & West Greenland fjords & IF & Jan 1988 & $330-430$ \\
$(6)$ & Denmark Strait & XIVb & Oct 1987 & $180-930$ \\
\hline
\end{tabular}


clature of the enzymes in this study was the same as that used by Fairbairn (1981) for the mutually studied enzymes except for glucosephosphate isomerase (GPI), which was designated as PHI by Fairbairn. The other enzymes were named according to Shows et al. (1979). The following enzymes were tested: adenosine deaminase (ADA), creatine phosphate kinase, esterase, glucosephosphate isomerase (GPI), glutamic oxaloacetic transaminase, alpha-glycerophosphate dehydrogenase, isocitric acid dehydrogenase (ICD), lactate dehydrogenase, malate dehydrogenase (MDH), mannosephosphate isomerase, phosphoglucomutase (PGM) and superoxid dismutase. Only ADA, GPI, ICD, $\mathrm{MDH}$ and $\mathrm{PGM}$ were polymorphic. The six other enzymes did not reveal more than one zymogram among 50 individuals, and hence were not useful for the study of divergence between populations. The buffer system used for GPI was the one described by Clayton and Tretiak (1972). The buffer system used for the remaining four enzymes was as described by Ayala et al. (1972). Heart tissue was used for GPI, MDH and PGM, liver for ICD and muscle for ADA. The staining procedures used for the five enzymes were as described by Frydenberg and Simonsen (1973).

Counts on a discontinuous variable, such as a meristic character, are distributed over a finite range of integral values and are not normally distributed. Therefore counts were analyzed with nonparametric statistical tests. Genotypic frequencies were tested for fit to Hardy-Weinberg expectations $(t)$, using $t=F(\sqrt{N}), F$ being the inbreeding coefficient and $N$ the sample size (Brown, 1970). Allele frequency differences between populations were tested for homogeneity using replicated G-test (likelihood-ratio test, Sokal and Rohlf, 1981).

\section{Results}

\section{Meristic characters}

Greenland halibut in the length range $50-70 \mathrm{~cm}$ cover several age groups and the average of meristic values can vary with year-class. Data were too sparse to allow an analysis by individual year-classes. Because growth rate of Greenland halibut in the length range covered is nearly linear, a Spearman Correlation Coef- ficient relating meristic value to total length was calculated and the null hypothesis that there was no correlation between the two variables was tested (Table 2). Both positive and negative correlations were obtained and the Spearman Correlation Coefficient differed significantly from zero in only three cases. Therefore, it seemed unlikely that significant bias in meristic average due to year-class differences occurred in this material.

Difference of meristic characters between sexes was tested by Wilcoxon 2-sample test (SAS anon., 1985). Only the left pectoral fin rays in the sample from Newfoundland was found to differ significantly (at the $5 \%$ level) between males and females. Thus differences in meristic characters between sexes were negligible. Males and females were therefore combined for subsequent comparisons.

Knowledge of possible correlation between meristic characters is useful when evaluating differences in average of characters. It lends support to conclusions if correlated characters show the same trend among areas. Spearman Correlation Coefficients relating numbers of left to right pectoral fin rays, and anal fin rays to dorsal fin rays, showed a high correlation $(P<0.0001)$ in each case. A significant $(P<0.005)$ correlation between numbers of anal fin rays and vertebrae was found in only one sample, West Greenland fjords, Div. $1 \mathrm{~A}$. When relating numbers of dorsal fin rays and vertebrate, significant correlations were found in the sample from West Greenland fjords, Div. 1A $(P<0.01)$ and in those from Newfoundland, $(P<0.005)$.

The left and right pectoral fin ray numbers ranged from 11 to 16 (Table 3). The greatest difference in mean numbers of fin rays in the left pectoral fin was found between the sample from the Denmark Strait and that from Newfoundland, and for the right pectoral fin between the West Greenland fjords (Div. 1D) and Newfoundland. Mean anal fin ray numbers ranged from 64 to 87 and mean dorsal fin ray numbers from 85 to 109 . The greatest difference in mean anal and dorsal fin ray numbers were found between samples from the Denmark Strait and those from the Davis Strait. A KruskalWallis test for difference between areas in fin ray

TABLE 2. Spearman correlation coefficients of each meristic character of Greenland halibut with length. Number of fish in parenthesis.

\begin{tabular}{|c|c|c|c|c|c|c|}
\hline $\begin{array}{l}\text { Site } \\
\text { No. }\end{array}$ & Location & $\begin{array}{c}\text { Pectoral fin } \\
\text { rays, left }\end{array}$ & $\begin{array}{c}\text { Pectoral fin } \\
\text { rays, right }\end{array}$ & $\begin{array}{c}\text { Anal } \\
\text { fin rays }\end{array}$ & $\begin{array}{l}\text { Dorsal } \\
\text { fin rays }\end{array}$ & Vertebrae \\
\hline (1) & Newfoundland & $0.201 \quad(91)$ & $0.162(87)$ & $0.060 \quad(99)$ & $0.035 \quad(99)$ & $0.046 \quad(94)$ \\
\hline (2) & Davis Strait & $0.088 \quad(98)$ & $0.069(100)$ & $0.178 \quad(98)$ & $0.160 \quad(98)$ & $-0.023(100)$ \\
\hline (3) & West Greenland fjords & $0.063 \quad(85)$ & $0.033(89)$ & $0.046 \quad(87)$ & $0.181 \quad(86)$ & $0.308(92)^{b}$ \\
\hline (4) & West Greenland fjords & 0.156 & $0.219(93)^{a}$ & $0.088 \quad(94)$ & $0.138 \quad(92)$ & $0.170(100)$ \\
\hline (5) & West Greenland fjords & $-0.084(101)$ & 0.002 (99) & $-0.028(101)$ & $-0.097(100)$ & $0.163(103)$ \\
\hline (6) & Denmark Strait & $0.157 \quad(89)$ & $0.207(94)^{\mathrm{a}}$ & $-0.141 \quad(93)$ & $-0.027 \quad(91)$ & $-0.037 \quad(97)$ \\
\hline
\end{tabular}

\footnotetext{
a Significance at the $95 \%$ level.

b Significance at the $99 \%$ level.
} 
numbers indicated no significant difference at the $5 \%$ level (left pectoral fin: $P=0.478$, right pectoral fin: $P=$ 0.057 , anal fin: $P=0.171$ and dorsal fin: $P=0.281$ ). However, there was an overall tendency for fish from the Denmark Strait to have the lowest mean values (Table 3).

Numbers of vertebrae ranged from 57 to 64 and means for areas ranged from 60.126 for West Greenland fjords (Div. 1D), to 61.693 for West Greenland fjords, Div. 1F (Table 4). A Kruskal-Wallis test showed significant $(P<0.0001)$ heterogeneity between areas. Pairwise tests (Wilcoxon 2-sample test) showed significant difference at the $5 \%$ level between the sample from Newfoundland and that from the Davis Strait, but no difference between the former and that from the Denmark Strait, nor between the samples from the Denmark Strait and from the Davis Strait. Samples from the West Greenland fjords differed significantly from those of the other areas as well as among themselves.

\section{Biochemical markers}

Descriptions of the zymograms for the six enzymes used were as follows:

ADA. Either single banded or double banded phenotypes were observed, and at least seven different rates of migration towards the anode were seen. The interpretation of the zymograms fits the hypothesis that a single locus with seven codominant alleles is responsible for the observed variation.

GPI. The observed zymograms were similar to those observed by Fairbairn (1981), and were explained as two loci Gpi-1 with four and Gpi2 with three alleles. In this study a few rare alleles were also observed for Gpi-2.

ICD. The variation observed in the zymograms for this enzyme is explained by assuming one locus with four codominant alleles.

TABLE 3. Summary statistics ior numbers of fin rays of Greenland halibut in different sites.

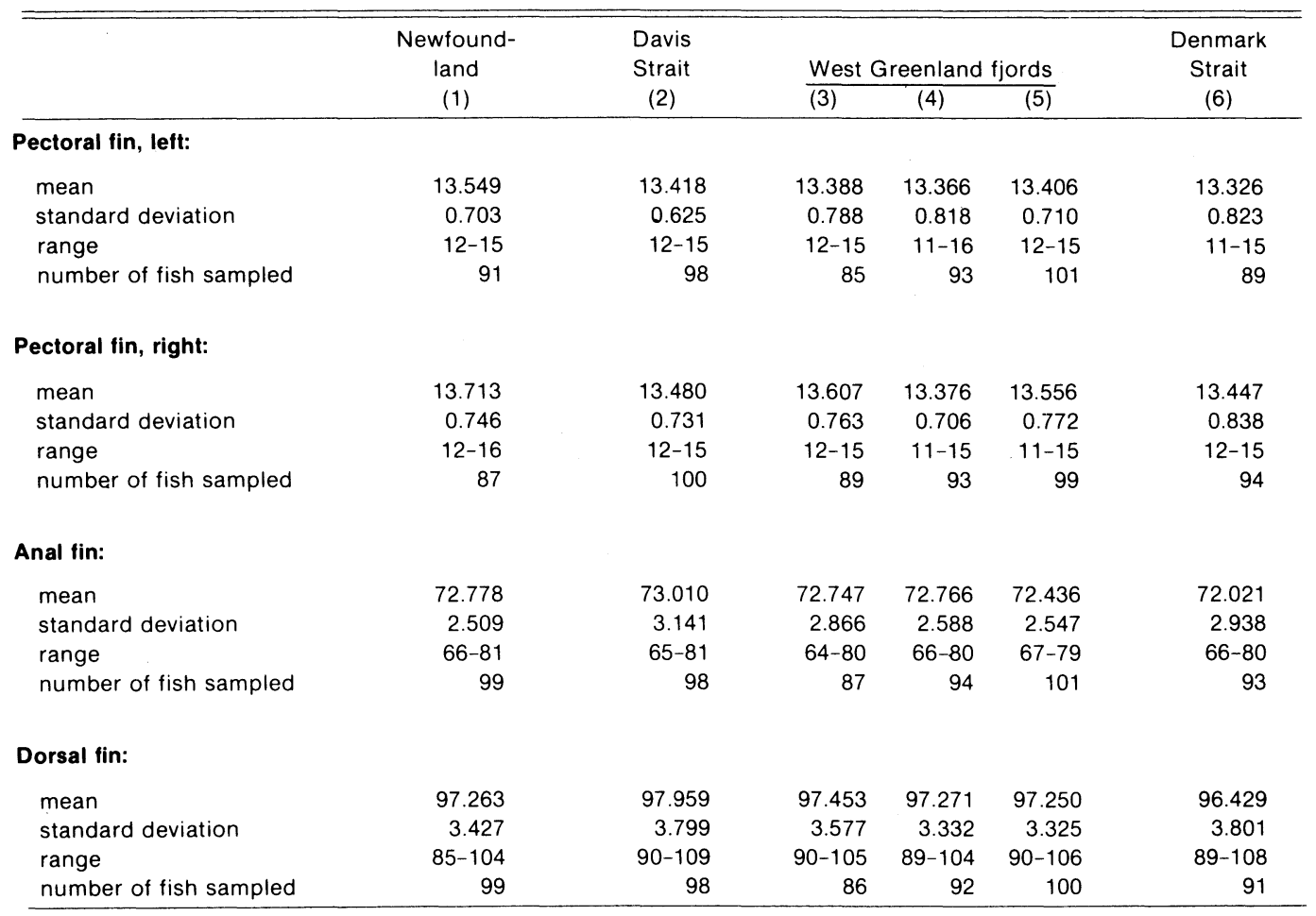

TABLE 4. Frequency distributions of vertebral counts of Greenland halibut in different sites and summary statistics ( $N$ = number of fish sampled, $X=$ mean number of vertebrae, S.D. = standard deviation).

\begin{tabular}{llrrrrrrrrrrr}
\hline & & \multicolumn{1}{c}{ Number of vertebrae } \\
\cline { 3 - 13 } Sites & \multicolumn{1}{c}{ Location } & 57 & 58 & 59 & 60 & 61 & 62 & 63 & 64 & $N$ & X & S.D. \\
\hline$(1)$ & Newfoundland & & 1 & 1 & 16 & 49 & 20 & 7 & & 94 & 61.138 & 0.899 \\
$(2)$ & Davis Strait & & & & 6 & 48 & 40 & 6 & & 100 & 61.460 & 0.702 \\
$(3)$ & West Greenland fjords & & 1 & 3 & 28 & 36 & 18 & 2 & & 88 & 60.830 & 0.913 \\
$(4)$ & West Greenland fjords & 3 & 5 & 14 & 38 & 26 & 8 & 1 & & 95 & 60.126 & 1.160 \\
$(5)$ & West Greenland fjords & & & 1 & 11 & 26 & 44 & 18 & 1 & 101 & 61.693 & 0.956 \\
$(6)$ & Denmark Strait & & & 6 & 16 & 25 & 40 & 9 & & 96 & 61.313 & 1.059 \\
\hline
\end{tabular}


$\mathrm{MDH}$. The observed phenotypes were similar to those found by Fairbairn (1981), while in addition in this study two rare alleles for $\mathbf{M d h}-\mathbf{1}$ were revealed. Mdh-2 showed no variation.

PGM. This investigation revealed only five alleles whereas Fairbairn (1981) observed six codominant alleles for the locus of this enzyme. Otherwise the results were similar to those of Fairbairn.

Table 5 lists the allelic frequencies for the observed variation within the localities, and Table 6 the number of individuals scored and the value of the testator for fit to Hardy-Weinberg expectations. The tests for HardyWeinberg proportions are based on the assumption that each locus has two codominant alleles, a common allele and a combined allele consisting of all alleles except the common one. No tests for the loci Gpi-2 and Mdh-1 were performed as the frequencies of the most common allele was very close to 1.000 in both cases. Only one test value out of 24 was significant (Table 6). This was the number of significant values expected to occur by chance at the $5 \%$ level of significance. Seven of the values for the testator indicated an excess of heterozygotes and seventeen a deficit, but there was no obvious observation of a Wahlund effect (Wahlund, 1928) except for the one significant test value.

Table 7 lists the values for the G-tests for homogeneity of the allelic frequencies between the localities. The test values were estimated under the assumption that each locus had two alleles as described in the previous paragraph, and the distribution of G-values could be approximated by the chi-square distribution. None of the samples showed homogeneity with all the other samples, and the sample from Newfoundland revealed significant difference in four out of five cases when compared with the samples from the other localities. This indicated that the samples from the six localities did not belong to the same breeding group.

\section{Discussion}

The number of fin rays and vertebrae in fish are determined during their early larval development. They are influenced by environmental conditions, especially temperature (Tåning, 1952). It has been shown that, the lower the temperature in the early life stages the higher

TABLE 5. Allelic frequencies for the six loci studied in Greenland halibut but from different sampling sites.

\begin{tabular}{|c|c|c|c|c|c|c|c|}
\hline Locus & Allele & $\begin{array}{l}\text { Newfound- } \\
\text { land } \\
\text { (1) }\end{array}$ & $\begin{array}{c}\text { Davis } \\
\text { Strait } \\
\text { (2) }\end{array}$ & $\frac{\text { West C }}{(3)}$ & $\frac{\text { reenlan }}{(4)}$ & $\frac{d \text { fjords }}{(5)}$ & $\begin{array}{c}\text { Denmark } \\
\text { Strait } \\
(6)\end{array}$ \\
\hline \multirow[t]{7}{*}{ Ada } & 1 & 0.012 & 0.035 & 0.006 & 0.046 & & 0.015 \\
\hline & 2 & 0.023 & 0.066 & 0.038 & 0.051 & 0.025 & 0.112 \\
\hline & 3 & 0.236 & 0.318 & 0.236 & 0.240 & 0.221 & 0.301 \\
\hline & $4^{a}$ & 0.580 & 0.384 & 0.420 & 0.459 & 0.539 & 0.429 \\
\hline & 5 & 0.126 & 0.157 & 0.250 & 0.153 & 0.157 & 0.107 \\
\hline & 6 & 0.023 & 0.035 & 0.042 & 0.046 & 0.054 & 0.036 \\
\hline & 7 & & 0.005 & 0.005 & 0.005 & 0.004 & \\
\hline \multirow[t]{4}{*}{ Gpi-1 } & 9 & & & & & & 0.005 \\
\hline & 1 & 0.253 & 0.270 & 0.278 & 0.320 & 0.303 & 0.313 \\
\hline & $2^{a}$ & 0.742 & 0.725 & 0.712 & 0.680 & 0.683 & 0.677 \\
\hline & 3 & 0.005 & 0.005 & 0.010 & & 0.014 & 0.005 \\
\hline \multirow[t]{3}{*}{ Gpi-2 } & 1 & 0.005 & 0.005 & 0.005 & 0.005 & & \\
\hline & $2^{a}$ & 0.995 & 0.985 & 0.995 & 0.995 & 1.000 & 1.000 \\
\hline & 3 & & 0.010 & & & & \\
\hline \multirow[t]{4}{*}{ Icd } & 1 & 0.022 & & 0.009 & 0.005 & 0.020 & 0.011 \\
\hline & $2^{a}$ & 0.860 & 0.865 & 0.836 & 0.879 & 0.840 & 0.865 \\
\hline & 3 & 0.118 & 0.135 & 0.146 & 0.111 & 0.130 & 0.118 \\
\hline & 4 & & & 0.009 & 0.005 & 0.010 & 0.006 \\
\hline \multirow[t]{3}{*}{ Mdh-1 } & 1 & 0.046 & 0.025 & 0.009 & 0.005 & 0.010 & 0.005 \\
\hline & $2^{a}$ & 0.954 & 0.975 & 0.991 & 0.995 & 0.990 & 0.990 \\
\hline & 3 & & & & & & 0.005 \\
\hline \multirow[t]{5}{*}{ Pgm } & 9 & 0.006 & 0.005 & 0.005 & & & 0.005 \\
\hline & 1 & 0.066 & 0.045 & 0.038 & 0.036 & 0.014 & 0.089 \\
\hline & 2 & 0.126 & 0.136 & 0.132 & 0.188 & 0.091 & 0.166 \\
\hline & $3^{a}$ & 0.802 & 0.809 & 0.825 & 0.776 & 0.890 & 0.740 \\
\hline & 4 & & 0.005 & & & 0.005 & \\
\hline
\end{tabular}

a Selected as the common allele. 
TABLE 6. Number of Greenland halibut scored $(N)$ and values for testator for HardyWeinberg proportions $(F \sqrt{N})$ at four loci at the six sampling sites.

\begin{tabular}{|c|c|c|c|c|c|c|c|}
\hline \multirow[b]{2}{*}{ Locus } & & \multicolumn{6}{|c|}{ Area sampled } \\
\hline & & $\begin{array}{l}\text { Newfound- } \\
\text { land } \\
(1)\end{array}$ & $\begin{array}{c}\text { Davis } \\
\text { Strait } \\
(2)\end{array}$ & \multicolumn{3}{|c|}{ West Greenland fjords } & $\begin{array}{c}\text { Denmark } \\
\text { Strait } \\
(6)\end{array}$ \\
\hline \multirow[t]{2}{*}{ Ada } & $\mathrm{N}$ & 87 & 99 & 106 & 98 & 102 & 98 \\
\hline & $F \sqrt{N}$ & 0.743 & -0.249 & -1.069 & 0.137 & 0.535 & $2.062^{a}$ \\
\hline \multirow[t]{2}{*}{ Gpi-1 } & $\mathrm{N}$ & 93 & 100 & 104 & 86 & 104 & 96 \\
\hline & $F \sqrt{N}$ & -0.646 & 0.219 & 1.599 & 0.598 & -1.119 & 0.046 \\
\hline \multirow[t]{2}{*}{ Icd } & $N$ & 89 & 100 & 106 & 99 & 100 & 89 \\
\hline & $F \sqrt{N}$ & 1.093 & 1.008 & 0.078 & 0.515 & -0.417 & -0.562 \\
\hline \multirow[t]{2}{*}{ Pgm } & $\mathrm{N}$ & 91 & 99 & 106 & 96 & 104 & 96 \\
\hline & $F \sqrt{N}$ & 0.290 & 0.229 & 0.520 & 0.696 & -0.271 & 1.849 \\
\hline
\end{tabular}

a Significance at the $95 \%$ level.

TABLE 7. Test values (G-tests) for homogeneity of the allelic distribution of Greenland halibut among the six sampling sites

\begin{tabular}{lccccc}
\hline \hline & \multicolumn{4}{c}{ Area sampled } \\
\cline { 2 - 6 } & $\begin{array}{c}\text { Davis } \\
\text { Strait }\end{array}$ & West Greenland fjords & $\begin{array}{c}\text { Denmark } \\
\text { Strait }\end{array}$ \\
\cline { 3 - 6 } Area sampled & $(2)$ & $(3)$ & $(4)$ & $(5)$ & $(6)$ \\
\hline Newfoundland (1) & $14.63^{\mathrm{a}}$ & $11.17^{\mathrm{a}}$ & 7.79 & $13.12^{\mathrm{a}}$ & $12.57^{\mathrm{a}}$ \\
Davis Strait (2) & & 1.58 & 3.96 & 9.11 & 4.51 \\
West Greenland fjords (3) & & & 4.28 & 4.68 & 5.69 \\
West Greenland fjords (4) & & & & $10.65^{\mathrm{a}}$ & 1.23 \\
West Greenland fjords (5) & & & & & \\
\hline
\end{tabular}

a Significance at the $95 \%$ level.

the number of vertebrae (Templeman and Pitt, 1961). Differences in meristic characters between areas will therefore indicate that larval stages have been exposed to different environmental conditions, and this may be interpreted as existence of geographically separated spawning stocks.

The number of anal and dorsal fin rays in fishes are not necessarily correlated with number of vertebrae which may be determined earlier in life (Tåning, 1952). In the present study the number of vertebrae and fin rays of Greenland halibut were not closely related, which is in accordance with the findings of Templeman (1970). Therefore, the number of fin rays and vertebrae cannot necessarily be expected to show the same trend between samples. Left and right pectoral fin ray numbers, and dorsal and anal fin ray numbers were in each case highly correlated. However, no significant differences in terms of number of pectoral, anal or dorsal fin rays were found between any of the samples. Although there was a tendency for the number of fin rays to be lowest in the Denmark Strait sample (Table $3)$, fin ray numbers do not seem useful in stock separation studies of Greenland halibut.

The number of vertebrae showed significant heterogeneity between areas. The Newfoundland and Davis
Strait samples were significantly different at the $5 \%$ level. This is in contrast to the findings by Templeman (1970) in a study which included samples from the West Greenland area. The meristic study by Misra and Bowering (1984) did not include samples from the West Greenland area. They suggested, however, that apart from evidence for local spawning in the Gulf of St. Lawrence and Fortune Bay, Greenland halibut form one continuous stock from the Davis Strait to the northern Grand Bank. Taking into account the results of these previous studies and the small differences between the Newfoundland and Davis Strait samples found in the present study, the result can hardly be interpreted as evidence of a stock separation.

The sample from the Denmark Strait was not significantly different from the Newfoundland and the Davis Strait samples in terms of mean number of vertebrae, although spawning is known to occur in both the Denmark Strait and the Davis Strait area. However, Greenland halibut is known to spawn in deep water (Jensen, 1935), and at these depths the environmental conditions usually are very uniform so that differences in mean number of vertebrae are unlikely to occur. Thus Greenland halibut from the offshore areas of the Northwest Atlantic are not different from each other in terms of mean number of vertebrae. 
The mean numbers of vertebrae in samples from West Greenland fjords differed from those in the offshore samples, although some of the values were close to each other. The most conspicuous differences were those among the West Greenland fjords themselves, indicating isolation between them. It is not possible from this study alone to judge the degree of isolation between the inshore fish of West Greenland fjords and offshore fish. Some supporting evidence was seen when recaptures from tagging experiments carried out in the fjords came from the fjords they were tagged in, apart from a few long distance migrants (Riget and Boje, 1989). However, it was not conclusive because very little offshore fishing occurred in the period of tagging, so recaptures outside the fjords must be expected to be rare. Subsequent tagging experiments in fjords of Southwest Greenland resulted in a relatively high number of recaptures being reported from Icelandic waters, indicating some migration out of these fjords (Boje, MS 1990). On the other hand, recruitment to the fjords seems to occur from the offshore areas (Smidt, 1969; Riget and Boje, 1989), but some spawners and spent individuals have been observed in the fjords (Smidt, 1969; Boje and Riget, MS 1988) showing that spawning may occur in fjords, at least sporadically.

The stock complexity in the West Greenland area seems to be very much like that in eastern Canada. The Gulf of St. Lawrence stock differs from the stock in the offshore area of Labrador and Newfoundland genetically (Fairbairn, 1981), in mean number of vertebrae (Templeman, 1970) and parasite prevalence (Khan et al., 1982). In the Gulf of St. Lawrence mature individuals have been observed (Templeman, 1970), but some recruitment to the Gulf of St. Lawrence through the Strait of Belle Isle from the offshore areas is believed to occur (Fairbairn, 1981; Bowering and Chumakov, 1989).

The mean number of vertebrae in samples from West Greenland fjords in Div. 1F was not especially close to that of the Denmark Strait sample. On the other hand, the highest mean value was found in Div. 1F which could be an indication of eggs/larvae being carried by the cold East Greenland current from the East Greenland/Iceland area to south West Greenland.

The study by Fairbairn (1981) revealed the polymorphic loci Gpi-1 and Pgm. The present study has shown variation in four additional loci, namely Ada, Gpi-2, Icd and Mdh-1, but the variation found in Gpi-2 and $\mathbf{M d h}-\mathbf{1}$ was not of such a magnitude that they could be used for stock identification. The allelic frequencies in both studies were rather similar for the two mutually studied loci (Gpi-2 and Pgm), but the additional loci showed rather small differences among the different localities (Table 5). The study by Fairbairn (1981) and the present study both reveal a rather low level of diver- gence of the Greenland halibut in the Northwest Atlantic. Even the sample from the Denmark Strait had very similar allelic frequencies.

The pair comparisons among the samples from the different localities (Table 7) showed that the samples could not be from a single spawning unit. Fairbairn (1981) and Dey (1982) both concluded that fish in the Gulf of St. Lawrence and off Newfoundland and Labrador show genetic divergence. Present results also show that there is some genetic divergence among Greenland halibut from different localities but the material is not sufficient to estimate how many spawning units exist in the Northwest Atlantic and how much intermixing takes place. Tagging experiments have shown that long distance migration occurs (Riget and Boje, 1989; Boje, MS 1990) and this could explain the low divergence between samples.

In summary, the analyses of genetic variation show a low level of divergence between samples from the Northwest Atlantic including the Denmark Strait. However, due to the lack of homogeneity in allelic frequencies, it can be concluded that more than one spawning stock must be present. The mean number of vertebrae from the samples from the offshore areas show only minor differences, while significant differences occur among West Greenland fjords. This supports the hypothesis that Greenland halibut in the fjords of West Greenland may be somewhat isolated from the Davis Strait stock. The present study could not support nor reject the hypothesis, that the stock in the southernmost fjords of West Greenland are to some extent recruited from the East Greenland/Iceland area.

\section{Acknowledgements}

The authors thank colleagues at Northwest Atlantic Fisheries Centre in St. John's, especially W. R. Bowering, for collecting the material from Div. 3K, and O. A. Jørgensen at our institute for the sampling in Div. $1 C$ and Subarea XIVb. The comments of S. A. Horsted on the manuscript were most helpful and are greatly appreciated by the authors.

\section{References}

AYALA, F. J., J. R. POWELL, M. L. TRACY, C. A. MOURRO, and S. PEREZ-SALES. 1972. Enzyme variability in the Drosophila willistoni group. IV. Genetic variation in natural populations of Drosophila willistoni. Genetics, 70: 113-139.

BOJE, J. MS 1990. On recaptures of Greenland halibut in Icelandic waters from tagging experiments in West Greenland fjords. NAFO SCR Doc., No. 37, Serial No. N1754, 2 p.

BOJE, J., and F. RIGET. MS 1988. Maturity stages in March and August of Greenland halibut in Div. 1A, West Green- 
land. NAFO SCR Doc., No. 13, Serial No. N1449, 7 p.

BOWERING, W. R., and A. K. CHUMAKOV. 1989. Distribution and relative abundance of Greenland halibut (Reinhardtius hippoglossoides (Walbaum)) in the Canadian Northwest Atlantic from Davis Strait to the Northern Grand Bank. Fish. Res., 7: 301-327.

BROWN, A. D. H. 1970. The estimation of Wright's fixation index from genotype frequencies. Genetics, 41: 399-406.

CLAYTON, J. W., and D. N. TRETIAK. 1972. Amine-Citrate buffers for $\mathrm{Ph}$ control in starch gel electrophoresis. J. Fish. Res. Board Can., 29: 1169-1172.

DEY, A. C. 1982. Comparison of the properties of phosphoglucomutase from muscle of turbot (Reinhardtius hippoglossoides, Greenland halibut) and witch flounder (Glyptocephalus cynoglossus) from the Northwest Atlantic and the Gulf of St. Lawrence. Comp. Biochem. Physiol., 72: 249-254.

FAIRBAIRN, D. J. 1981. Biochemical genetic analysis of population differentiation in Greenland halibut (Reinhardtius hippoglossoides) from the Northwest Atlantic, Gulf of St. Lawrence, and Bering Sea. Can. J. Fish. Aquat. Sci., 38: 669-677.

FRYDENBERG, O., and V. SIMONSEN. 1973. Genetics of Zoarces, V. Amount of protein polymorphism and degree of genetic heterozygosity. Hereditas, 75: 221-232.

JENSEN, Ad. S. 1935. The Greenland halibut (Reinhardtius hippoglossoides) its development and migrations. $K$. Danske Vidensk. Selsk. Skr.,9 RK. 6(4): 1-32.

KHAN, R. A., M. DAWE, R. BOWERING, and R. K. MISRA. 1982. Blood protozoa as an aid for separating stocks of Greenland halibut (Reinhardtius hippoglossoides) in the Northwest Atlantic. Can. J. Fish. Aquat. Sci., 39: 13171322.

MISRA, R. K., and W. R. BOWERING. 1984. Stock delineation of Greenland halibut in the Northwest Atlantic using a recently developed, multivariate statistical analysis based on meristic characters. North. Amer. J. Fish. Manag., 4: 390-398.
RIGET, F., and J. BOJE. 1989. Fishery and some biological aspects of Greenland halibut at West Greenland. NAFO Sci. Coun. Studies, 13: 41-52.

SAS Institute Inc. 1985. SAS User's Guide: Statistics, version 5 Edition. Cary, NC: SAS Institute Inc., 956 p.

SHOWS, T. B., C. A. ALPER, D. BOOTSMA, M. DORF, T. DOUGLAS, T. HUISMAN, H. P. KLINGER, C. KOZAK, P. A. LALLEY, D. LINDSLEY, P. J. MCALPINE, J. K. MCDOUGALL, P. MERRA KHAN, M. MEISLER, N. E. MORTON, J. M. OPITZ, C. W. PARTRIDGE, R. PAYNE, T. H. RODERIK, P. RUBENSTEIN, F. H. RUDDLE, M. SHAW, J. W. SPRANGER, and K. WEISS. 1979. International system for human gene nomenclature (1979). Cytogenet. Cell Genet., 25: 96-116.

SIGURDSSON, A. MS 1980. On the nursery grounds of the Greenland halibut spawning in Icelandic waters. ICES C.M. Doc., No. G:45.

SMIDT, E. 1969. The Greenland halibut, Reinhardtius hippoglossoides (Walb.), biology and exploitation in Greenland waters. Medd. Danm. Fisk.-og Havunders., N.S., 6: 79-148.

SOKAL, R. R., and F. J. ROHLF. 1981. Biometry (second edition) San Francisco, W. H. Freeman and Co.

TEMPLEMAN, W., and T. K. PITT. 1961. Vertebral numbers of redfish, Sebastes marinus (L.), in the North-West Atlantic, 1947-1954. ICES Rapp. Proc.-Verb., 150: 56-89.

TEMPLEMAN, W. 1970. Vertebral and other meristic characteristics of Greenland halibut, Reinhardtius hippoglossoides, from the Northwest Atlantic. J. Fish. Res. Board Can., 27: 1549-1562.

1973. Distribution and abundance of Greenland halibut, Reinhardtius hippoglossoides (Walbaum), in the Northwest Atlantic. ICNAF Res. Bull., 10: 83-98.

TÅNING, A. V. 1952. Experimental study of meristic characters in fishes. Biol. Rev., 27: 169-193.

WAHLUND, S. 1928. The combination of populations and the appearance of correlation examined from the standpoint of the study of heredity. Hereditas, 11: 65-106. 